\title{
A Review of Feeding Behavior, Growth, Reproduction and Aquaculture Site Selection for Green-Lipped Mussel, Perna viridis
}

\author{
Tan Kar Soon, Julian Ransangan* \\ Microbiology and Fish Disease Laboratory, Borneo Marine Research Institute, University Malaysia Sabah, \\ Kota Kinabalu, Malaysia \\ Email: "liandra@ums.edu.my
}

Received 12 February 2014; revised 14 March 2014; accepted 27 March 2014

Copyright (C) 2014 by authors and Scientific Research Publishing Inc.

This work is licensed under the Creative Commons Attribution International License (CC BY). http://creativecommons.org/licenses/by/4.0/

(c) (i) Open Access

\begin{abstract}
Green-lipped mussel, Perna viridis is a warm water mussel species that is distributed widely in the Indo-Pacific regions. It is a commercially important species and has demonstrated a great culture potential in tropical countries. The feeding behavior of $P$. viridis is influenced by both seston concentration and its nutritional values. It is shown the mussels exhibit higher ingestion rate when the organic content of the seston is higher. Interestingly, several studies have reported that $P$. viridis can demonstrate selective feeding behavior towards phytoplankton. Short term studies have shown that the $P$. viridis exhibits preferentially ingestion of dinoflagellates, while long term studies show that the $P$. viridis has a higher growth rate during diatom blooms. Nevertheless, spawning of $P$. viridis is induced by high primary productivity at relatively high sea water temperature. In the temperate countries, spawning is seasonal but normally occurs in summer. In the tropical countries, however, the $P$. viridis has been shown to spawn all year-round with two peaks which coincide with monsoon seasons. The site selection is critically important when considering the green mussel culture. Feasibility study for $P$. viridis farming is normally carried out first in order to evaluate the environmental conditions of the site. This paper attempts to review the current knowledge of biology, selective feeding behaviour, growth, reproductive and the aquaculture site selection methods for green-lipped mussel.
\end{abstract}

\section{Keywords}

Feeding Behavior; Growth; Reproduction; Green-Lipped Mussel

\footnotetext{
*Corresponding author.
}

How to cite this paper: Soon, T.K. and Ransangan, J. (2014) A Review of Feeding Behavior, Growth, Reproduction and Aquaculture Site Selection for Green-Lipped Mussel, Perna viridis. Advances in Bioscience and Biotechnology, 5, 462-469. 


\section{Introduction}

The green-lipped mussel also called green mussel, belongs to the family Mytilidae and species Perna viridis. Mytilidae is the family of saltwater mussels, and the only family in the order Mytiloida. The Mytilidae comprises of 32 genera, which include the Adipicola, Adula, Amygdalum, Arcuatula, Aulacomya, Bathymodiolus, Botula, Brachidontes, Choromytilus, Crenella, Dacrydium, Geukensia, Gigantidas, Gregariella, Idasola, Ischadium, Limnoperna, Lioberus, Lithophaga, Megacrenella, Modiolula, Modiolarca, Modiolus, Musculista, Musculus, Mytilaster, Mytilus, Perna, Rhomboidella, Septifer, Solamen, Stenolena, Trichomya, Vilasina, and Xenostrobus [1].

The genus Perna can be easily differentiated from other genera by its distinctive morphology. Unlike other members of Mytilidae, the anterior adductor is completely absent in Perna. In addition, Perna divided the retractor muscle complex, and developed primary lateral hinge teeth and branching papillae on the mantle margin [2]. The genus Perna consists of only four species, $P$. canaliculus, P. perna, P. picta, and P. viridis. Mussels of this genus are distributed worldwide with each species which seems to have established a specific geographical distribution. The New Zealand green-lipped mussel, $P$. canaliculus, occurs in the coastal water of New Zealand [3], whereas P. picta occurs in the Mediterranean waters [2]. P. perna is found widely distributed in the South America, Africa, Asia and India, while P. viridis is distributed widely in the Persian Gulf to the South-west Pacific longitudinally and from southern Japan to Papua New Guinea latitudinally [2].

The Perna viridis is a large (80 - $100 \mathrm{~mm})$ and fast growing bivalve. They usually occur at depths of less than $10 \mathrm{~m}$ and live for approximately three years [4]. They have two identical smooth and elongated shell valves, a pear-shaped and smooth exterior surface characterized by concentric growth lines and a slightly concave ventral margin. The shell surface of $P$. viridis is covered by a smooth and firm periostracum, which is bright green in juvenile, and brown with green margins in adult. Externally, it will be difficult to ascertain the sex of $P$. viridis. However, internally, the gonadal tissue of a sexually matured male appears creamy-white in colour, while that of the female is reddish. Therefore, mature female mussels have orange flesh, while mature male mussels have white flesh [1]. The foot of $P$. viridis is small, tongue-like in shape, with a groove on the ventral surface which is continuous with the byssal pit. In this pit, a viscous secretion is exuded, entering the groove and hardening gradually upon contact with sea water. This forms extremely tough, firm, elastic, byssal threads that secure the mussel to hard substrates [4].

\section{Feeding Behavior and Assimilation Efficiency}

$P$. viridis is a cilliary-mucus suspension feeder. As a result of this feeding mechanism, mussels obtain their nutritional requirements from the environment. Green mussels and most other bivalves are known to preferentially ingest high organic particles from the filtered matter and selectively reject the inorganic particles [5]. Like other mussels, the $P$. viridis feeds by pumping water through a set of gill filaments which filter out small particles such as phytoplankton, zooplankton and other organic materials from the water, while the water and sediment are discharged through the excurrent siphon. Only appropriately sized food particles are retained, and passed into the stomach where it is digested [1].

High phytoplankton biomass usually results in fast growth and increase in condition of $P$. viridis [6]. Chlorophyll-a pigment concentration is often used to estimate phytoplankton biomass in field monitoring and, therefore, can be used as an indicator of environmental conditions that influence mussel growth. The chlorophyll-a distribution ranged from 0.7 to $17 \mu \mathrm{g} / \mathrm{l}$ was reported to favor the $P$. viridis culture [7]. However, poor mussel growth in moderate levels of chlorophyll-a has also been documented [8], suggesting the feeding behavior of bivalves is affected by food quantity and quality [9] [10]. Study of other species of mussels have shown that the ingestion rates of Mytilus trossulus [11], Cerastoderma edule [9] and Mytilus edulis [12], were increased with increased in organic content of seston. In addition, the absorption rate of bivalve also influenced by the changes in both seston concentration and its nutritional values. The maximum absorption rate for particulate organic matter by $P$. viridis was recorded at $5.3 \mathrm{mg} / \mathrm{l}$ [10], while Mytilus trossulus has been reported to have maximum absorption rate up to $1.9 \mathrm{mg} / \mathrm{l}$ [12]. Nevertheless, no correlation between absorption rate and particulate organic matter was established in Mytilus galloprovincialis [13].

The differential utilization of phytoplankton by bivalves, can be examined on the basis of phytoplankton composition between gut and the water column. Many studies have documented no selective feeding in bivalves due to similar patterns of seasonal variation of phytoplankton composition in seawater and the stomach of bi- 
valves [14] [15]. However, other studies demonstrated that the stomach content of Mytilus edulis and Brachidontes exustus [16] did not reflect the occurrence of diatom blooms recorded in the culture areas. The stomach fluids have been shown to contain much higher percentage of dinoflagellates and chlorophyta than that in the surrounding water [16] [17]. In addition, the species diversity of phytoplankton was lower in the stomach compared to the surrounding water, supporting the theory of selective ingestion in bivalves.

Assimilation efficiency in bivalves is known to highly dependant on the phytoplankton genera and species [18]. P. canaliculus has shown higher assimilation efficiency when fed on dinoflagellates (84.5\%) and flagellates (77.9\%), compared to diatom (61.7\%) [18]. In addition, Mytilus galloprovincialis was also demonstrated to preferentially ingest dinoflagellates rather than diatoms [19]. In fact, bivalve species such as oyster, Crassostrea virginica has been documented to hardly digest diatoms particularly Platymonas suecica, due to the rigid cell walls of the diatoms, which are resistant to enzymatic digestion and physical breakdown [20]. However, long term field observation of the growth of Macoma balthica and phytoplankton composition for 15 years concluded that, faster growth and better condition were achieved at higher abundance of diatoms than during the time flagellates were dominant [21]. Study by Rouillon and Navarro [22] also suggested that M. edulis preferred diatom. Similarly, ribbed mussel, Geukensia demissa, has been shown to accumulate dinoflagellate cells in the feces suggesting that dinoflagellates are far more resistant to extracellular digestion [16].

\section{Growth}

Generally, growth of the bivalves can be distinguished into shell and body growth. The shell length does not necessarily reflect the meat content. During spawning or food shortage, internal energy reserves are consumed while the shell may continue to grow. P. viridis has been shown to have high growth rate up to $6-10 \mathrm{~mm}$ per month [4]. However, the growth rate is influenced by the age of mussel, where older mussels have poorer growth rate because of reduced metabolic activity [23], decline in filtration rate [24], and increase in gamete production [25]. Moreover, growth of bivalves is also highly influenced by environmental conditions such as turbidity, current speed, temperature, salinity, food availability, phytoplankton composition, and competition for space [26]-[29].

High turbidity (Secchi-disc reading of less than $25 \mathrm{~cm}$ ) was shown to negatively affect the mussel culture because it can result in failure of the filtering activities of green mussel [30]. Moreover, the low light penetration due to high turbidity also results in low primary productivity which causes insufficient supply of food and leads to failure of mussel culture. The current speed is another important factor determining the amount of food available for mussel culture. A poorer water movement often does not favourable to mussel growth [31], while too strong water current can result in high turbidity and causes settlement difficulty for young mussels. The optimal current speed in mussel farming was proposed to be in the range of $0.1-0.3 \mathrm{~m} / \mathrm{s}$ [30]. In addition, $P$. viridis is also known to tolerate wide ranges of salinity (5.2 ppt to $39.8 \mathrm{ppt}$ [ [7] and temperature $\left(10^{\circ} \mathrm{C}\right.$ to $\left.35^{\circ} \mathrm{C}\right)$ [32] [33]. The water salinity of $27 \mathrm{ppt}$ to $35 \mathrm{ppt}$ was reported to be the ideal salinity for mussel farming [31], while the optimum temperature was suggested between $25.3^{\circ} \mathrm{C}$ to $34.6^{\circ} \mathrm{C}$ [7], $27^{\circ} \mathrm{C}$ to $30^{\circ} \mathrm{C}$ [31] and $26^{\circ} \mathrm{C}$ to $32^{\circ} \mathrm{C}$ [4]. High salinities of 24 to $30 \mathrm{ppt}$ and temperatures of $26-32^{\circ} \mathrm{C}$ have shown to enhance filtration rate in P. viridis [4] [7] and significantly increase the condition index of the mussels [34].

\section{Life Cycle and Reproduction}

Reproduction of $P$. viridis is through sexual, where the sexes are separated (gonochoristic), and fertilization occurs externally. The life cycle of $P$. viridis starts with the release of gamets into the water. Soon after, the gametes begin to fuse and forms zygotes. Within eight hours of fertilization, $P$. viridis larvae reached a ciliated, free-swimming stage (trochophore stage). Eight to twelve hours later, the larvae will reach the veliger stage, which is characterized by the presence of a shell and a ciliated membrane or skirt called the velum. This veligar swims actively in the water column to feed on phytoplankton [4]. Mussel larvae usually settle first on the flexible filamentous surface such as seaweed when they reached about half a millimeter in size (usually 8 - 12 days). The primary attachment to filamentous substrates is to avoid competition with adult mussels and the risk of adults sucking them in. Once settled, mussel larvae metamorphosed into spat, a stage which gills are fully developed and capable of breathing and gathering food. The spat is still in the active mobile stage, where it can detach, move by crawling with their foot or drifting through the water by using their own mucus as parachutes (mucus drifting). At about two to five weeks old, at a larger, more competitive advantageous size, the young 
mussel will have to settle again, this time they undergo final metamorphosis and usually attached permanently to solid surfaces such as rocks, wood, ropes and on other mussels. Mussels become less mobile as they grow bigger. Settlement-stage individuals are capable of secreting byssal threads [35]. About 1 year of age, $P$. viridis are sexually mature and able to produce gametes.

Early study has shown that the spawning in marine epibenthic communities is influenced by phytoplankton abundance and only indirectly by temperature [36]. However, a recent study discovered that spawning period of P. viridis is associated with the seasonal distribution of temperature, rather than to food availability [7]. Different environmental conditions may also result in different spawning times and duration, as well as more subtle variations in gametogenic cycles [37] [38]. In temperate countries, the spawning season of $P$. viridis is generally associated with the rising of seawater temperature, which positively affect on gametogenesis of mussels and thereby inducing spawning to take place [39]. In tropical countries, $P$. viridis spawns year-round, however, the peak period of spawning and the setting has shown to closely related to monsoon seasons and occurs twice a year. Peak period of mussel spawning occurs during March to April and October to November [33], June to September [40], and April to May and again in September to October in Malaysia, India, and Philippines, respectively.

In addition, habitat also influences the reproduction of mussel, where sub-tidal mussel population has consistently higher gonad indices and higher percentage of ripe and spawning mussels compared to intertidal population [41]. Sub-tidal mussels tend to have a higher growth rate and reproductive efforts owing to the generally prolonged feeding period and lower stress from desiccation, temperature fluctuation and predation [42]. Therefore, the mussel population in sub-tidal zone may sustain prolonged reproductive maturity and reallocating energy from maintenance to reproduction.

\section{Feasibility Study for Green Mussel Farming}

Mussels are natural inhabitants of marine intertidal and subtidal zones. Marine mussels are widely cultivated for their proteinaceous meat and are considered ideal candidates for aquaculture [43]. The $P$. viridis is an ideal candidate for aquaculture due to its fast growing ability, and the reproduction can be induced throughout the year [33]. On one hand, the rapid growth rate of $P$. viridis enables them to compete successfully against other benthic organisms, and also can achieve the marketable size in a shorter culturing period. On the other hand, natural availability of seed throughout the year, without the need to resort hatchery production, has been a significant factor in encouraging the development of mussel farming.

$P$. viridis is a self regulated aquaculture and it required only a little effort in maintaining the culture. Therefore, proper selection of farming sites is the most important when considering green-lipped mussel aquaculture. Farming trials by suspending the $P$. viridis from off bottom structures in estuaries, semi-enclosed bay and open sea areas have given encouraging results [44]. However, the growth and gonad index of mussels are much higher in the sea and semi-enclosed bay than in estuaries [34]. The stable and relatively high salinity at sea and semi-enclosed bay not only promote the filtration rate of mussels, but also favour the gametogenesis.

In selecting sites for bivalve farming, determination of food abundance, natural availability of seed, lack of major predators and pests, current speed, mixing rates, temperature and salinity variations over an extended period of time would appear essential [43]. The first criteria in site selection for mussel farming should be in a well-protected or sheltered bay. Sites that exposed to strong wind and big waves must not be selected to avoid damages to the stock and culture materials. The favorable water depth for raft mussel farming should be at least $2 \mathrm{~m}$ above the sea floor during the low tide level of spring tides to prevent ground predators and high water turbidity [31]. In addition, the environmental parameters such as turbidity, current speed, salinity, and temperature, are generally the most critical in the site selection for P. viridis farming because they have been known to influence growth of mussels [30]. Water physio-chemical parameters are also important factors to be considered.

The site selection for $P$. viridis farming is usually done based on the examination of an array of environmental parameters, which represent the environmental conditions of the site. The environmental parameters such as water temperature, $\mathrm{pH}$, dissolved oxygen, salinity, transparency, water movement and water depth are given a weighted value, which ranges from 0.0 to 0.9 based on its effects to the growth or survival of the culture species (Table 1). The rated value of each parameter in the studied site is multiplied by the weighted value for the parameter in order to determine parameter weighted value of the site. The total parameter's weighted value will then be used to categorize the suitability of the sites for P. viridis farming (Table 2). 
Table 1. The assumption weighted value and assumption rating point for the range of environmental parameters for mussel farming based on [30]-[33] [43].

\begin{tabular}{|c|c|c|c|c|c|c|c|c|}
\hline & & Salinity (ppt) & Dissolved oxygen (mg/l) & $\mathrm{pH}$ & Temperature $\left({ }^{\circ} \mathrm{C}\right)$ & Turbidity (cm) & Water current $(\mathrm{m} / \mathrm{s})$ & Water depth \\
\hline \multirow{10}{*}{$\begin{array}{l}\text { Rating } \\
\text { point }\end{array}$} & 10 & $27-32$ & $>8$ & $7.9-8.2$ & $26-32$ & $25-22$ & $0.1-0.3$ & $>8$ \\
\hline & 9 & $25-33$ & $6-7$ & $7.8-8.3$ & $25-33$ & $26-21$ & $0.15-0.35$ & 8 \\
\hline & 8 & $24-34$ & $5-6$ & $7.7-8.4$ & $24-34$ & $30-19$ & $0.2-0.4$ & 7 \\
\hline & 7 & $23-35$ & $4-5$ & $7.6-8.5$ & $23-35$ & $35-17$ & $0.25-0.45$ & 6 \\
\hline & 6 & $18-36$ & $3-4$ & $7.5-8.6$ & $22-36$ & $40-15$ & $0.3-0.5$ & 5 \\
\hline & 5 & $15-40$ & - & $7.4-8.7$ & $21-37$ & $45-13$ & $0.35-0.6$ & 4 \\
\hline & 4 & $12-45$ & - & $7.3-8.8$ & $20-38$ & $50-12$ & $0.4-0.7$ & 3 \\
\hline & 3 & $10-50$ & $3-2$ & $7.0-8.9$ & $19-39$ & $55-10$ & $0.6-0.9$ & - \\
\hline & 2 & $5-55$ & $2-1$ & $6.9-9.0$ & $18-40$ & $60-8$ & $0.9-1.5$ & - \\
\hline & 1 & $0-65$ & - & $6.8-9.1$ & $17-41$ & $65-7$ & $>1.5$ & 1 \\
\hline $\begin{array}{l}\text { Weighted } \\
\text { value }\end{array}$ & & 0.15 & 0.15 & 0.10 & 0.15 & 0.15 & 0.15 & 0.15 \\
\hline
\end{tabular}

Note: The environmental parameters are rated based on its suitability for green mussel culture from 1 (unsuitable) to 10 (optimal). The environmental parameters are read as range, the maximum and minimum are graded based on the rating system.

Table 2. The category of the site based on assumed weight (Modified from [45]).

\begin{tabular}{|c|c|c|}
\hline Weighted category & Site evaluation & Recommendation \\
\hline $1.0-2.5$ & Not advisable & Not suitable for green mussel farming and cannot support the culture \\
\hline $2.6-5.0$ & Poor & May support green mussel but not recommended \\
\hline $5.1-7.5$ & Medium & Capable and moderately suitable for green mussel farming \\
\hline $7.6-10.0$ & Good & Suitable for green mussel farming and highly recommended \\
\hline
\end{tabular}

\section{Conclusions}

The green-lipped mussels contribute to the main protein food supply in local protein demand and occupy a significant position among the exploited mollusc resources from the coastal area of many tropical countries. A clear evidence of filter feeding behavior in utilizing a specific group of phytoplankton is demonstrated in $P$. viridis. However, there is still a vast gap in knowledge with regards to the preferential utilization of phytoplankton species by the mussel. Extended study is needed to elucidate the selective feeding behavior, assimilation efficiency and growth of $P$. viridis in different seston quantity and quality.

Spawning of $P$. viridis is generally induced by increasing the water temperature and food availability. However, the detail effects of environmental parameters and food availability on gametogenisis and spawning in $P$. viridis are still poorly understood. Further investigations are needed to gain more information on how certain environmental parameters and food availability can regulate the reproduction of $P$. viridis.

Nevertheless, the suitability of a coastal area for bivalve farming, as well as the density at which bivalves can be farmed in an area, is generally limited by the food availability and environmental parameters. Therefore, besides environmental features, other parameters such as phytoplankton density, tide, suspended sediment, disease, and fouling potential should also be taken into account in the weighted rating system in order to get a more precise result for culture site selection of green-lipped mussel.

\section{Acknowledgements}

This work was financially supported by a Nich Research Grant Scheme (NRGS0003) from the Ministry of 
Higher Education Malaysia.

\section{References}

[1] Cosling, E.M. (2003) Bivalve Molluscs: Biology, Ecology and Culture. Malden, Oxford, Fishing News Books. http://dx.doi.org/10.1002/9780470995532

[2] Siddall, S.E. (1980) A Clarification of the Genus Perna (Mytilidae). Bulletin of Marine Science, 30, 858-870.

[3] Apte, S., Star, B. and Gardner, J.P.A. (2003) A Comparison of Genetic Diversity Between Cultured and Wild Populations, and a Test for Genetic Introgression in the New Zealand Greenshell Mussel Perna canaliculus (Gmelin 1791). Aquaculture, 219, 193-220. http://dx.doi.org/10.1016/S0044-8486(03)00003-6

[4] Power, A.J., Walker, R.L., Payne, K. and Hurley, D. (2004) First Occurrence of the Nonindigenous Green Mussel, Perna viridis in Coastal Georgia, United States. Journal of Shellfish Research, 23, 741-744.

[5] Jorgensen, C.B. (1996) Bivalve Filter Feeding Revisited. Marine Ecology Progress Series, 142, 287-302. http://dx.doi.org/10.3354/meps142287

[6] Ren, J.S. and Ross, A.H. (2005) Environmental Influence on Mussel Growth: A Dynamic Energy Budget Model and Its Application to the Greenshell Mussel Perna canaliculus. Ecological Modelling, 189, 347-362. http://dx.doi.org/10.1016/j.ecolmodel.2005.04.005

[7] Rajagopal, S., Venugopalan, V.P., Nair, K.V.K., van der Velde, G., Jenner, H.A. and Den Hartog, C. (1998) Reproduction, Growth Rate and Culture Potential of the Green Mussel, Perna viridis (L.) in Edaiyur Backwaters, East Coast of India. Aquaculture, 162, 187-202. http://dx.doi.org/10.1016/S0044-8486(98)00166-5

[8] Ren, J.S. and Ross, A.H. (2002) What's Best for Mussels? Fish. Aquaculture Update, 5, 2.

[9] Iglesias, J.I.P., Urrutia, M.B., Navarro, E., Alvarez-Jorna, P., Larretxea, X., Bougrier, S. and Heral, M. (1996) Variability of Feeding Processes in Cockle Cerastoderma edule (L.,) in Response to Changes in Seston Concentration and Composition. Journal of Experimental Marine Biology and Ecology, 197, 121-143. http://dx.doi.org/10.1016/0022-0981(95)00149-2

[10] Wong, W.H. and Cheung, S.G. (1999) Feeding Behaviour of the Green Mussel, Perna viridis (L.): Responses to Variation in Seston Quantity and Quality. Journal of Experimental Marine Biology and Ecology, 236, 191-207. http://dx.doi.org/10.1016/S0022-0981(98)00207-X

[11] Arifin, Z. and Bendell-Young, L.I. (1997) Feeding Responses and Carbon Assimilation by the Blue Mussel Mytilus trossulus Exposed to Environmentally Relevant Seston Matrices. Marine Ecology Progress Series, 160, $241-254$. http://dx.doi.org/10.3354/meps160241

[12] Bayne, B.L., Hawkins, A.J.S., Navarro, E. and Iglesias, J.I.P. (1989) Effects of Seston Concentration on Feeding, Digestion and Growth in the Mussel Mytilus edulis. Marine Ecology Progress Series, 55, 47-54. http://dx.doi.org/10.3354/meps055047

[13] Navarro, E., Iglesias, J.I.P., Perez Camacho, A. and Labarta, U. (1996) The Effect of Diets of Phytoplankton and Suspended Bottom Material on Feeding and Absorption of Raft Mussels (Mytilus galloprovincialis Lmk). Journal of Experimental Marine Biology and Ecology, 198, 175-189. http://dx.doi.org/10.1016/0022-0981(95)00210-3

[14] Kamermans, P. (1994) Similarity in Food Source and Timing of Feeding in Deposit-and Suspension-Feeding Bivalves. Marine Ecology Progress Series, 104, 63-75. http://dx.doi.org/10.3354/meps104063

[15] Shumway, S., Selvin, R. and Shick, D. (1987) Food Resources Related to Habitat in the Scallop Placopecten magellanicus (Gmelin, 1791): A Qualitative Study. Journal of Shellfish Research, 6, 89-95

[16] Ciocco, N.F. and Gayoso, A.M. (2002) Microalgal Food of the Ribbed Mussel Aulacomya atra (Molina, 1782) in Golfo Nuevo (Patagonia, Argentina). Journal of Shellfish Research, 21, 497-501.

[17] Loret, P., Pastoureaud, A., Bacher, C. and Delesalle, B. (2000) Phytoplankton Composition and Selective Feeding of the Pearl Oyster Pinctada margaritifera in the Takapoto Lagoon (Tuamoto Archipielago, French Polynesia): In Situ Study Using Optical Microscopy and HPLC Pigment Analysis. Marine Ecology Progress Series, 199, 55-67. http://dx.doi.org/10.3354/meps199055

[18] Ren, J.S., Ross, A.H. and Hayden, B.J. (2000) Comparison of Assimilation Efficiency on Diets of Nine Phytoplankton Species of the Greenshell Mussel Perna canaliculus. Journal of Shellfish Research, 25, 887-892.

[19] Sidari, I., Nichetto, P., Cok, S., Sosa, S., Tubaro, A., Honsell, G and Della Loggia, R. (1998) Phytoplankton Selection by Mussel, and Diarrhetic Shellfish Poisoning. Marine Biology, 131, 103-111. http://dx.doi.org/10.1007/s002270050301

[20] Romberger, H.P. and Epifanio, C.E. (1981) Comparative Effects of Diets Consisting of One or Two Algal Species upon Assimilation Efficiencies and Growth of Juvenile Oysters, Crassostrea virginica (Gmelin). Aquaculture, 25, 
77-87. http://dx.doi.org/10.1016/0044-8486(81)90101-0

[21] Beukema, J.J. and Cadee, G.C. (1991) Growth Rates of the Bivalve Macoma Balthica in the Wadden Sea during a Period of Eutrophication: Relationships with Concentrations of Pelagic Diatoms and Flagellates. Marine Ecology Progress Series, 68, 249-256. http://dx.doi.org/10.3354/meps068249

[22] Rouillon, G. and Navarro, E. (2003) Differential Utilization of Species of Phytoplankton by the Mussel Mytilus edulis. Acta Oecologica, 24, S299-S305. http://dx.doi.org/10.1016/S1146-609X(03)00029-8

[23] Cheung, S.G. (1993) Population Dynamics and Energy Budgets of Green Mussel Perna viridis (Linnaeus) in Polluted Harbour. Journal of Experimental Marine Biology and Ecology, 168, 1-24. http://dx.doi.org/10.1016/0022-0981(93)90113-3

[24] Seed, R. and Suchanek, T.H. (1992) Population and Community Ecology of Mytilus. In: Gosling, E., Ed., The Mussel Mytilus: Ecology, Physiology, Genetics and Culture, Elsevier, London, 87-169.

[25] Hilbish, T.J. (1986) Growth Trajectories of Shell and Soft Tissue in Bivalves: Seasonal Variation in Mytilus edulis L. Journal of Experimental Marine Biology and Ecology, 96, 103-113. http://dx.doi.org/10.1016/0022-0981(86)90236-4

[26] Frechette, M. and Grant, J. (1991) An in Situ Estimation of the Effect of Wind-Driven Resuspension on the Growth of the Mussel Mytilus edulis L. Journal of Experimental Marine Biology and Ecology, 148, 201-213. http://dx.doi.org/10.1016/0022-0981(91)90082-8

[27] Alvarado, J.L. and Castilla, J.C. (1996) Tridimensional Matrices of Mussels (Perumytilus purpuratus) on Intertidal Platforms with Varying Wave Forces in Central Chile. Marine Ecology Progress Series, 133, 135-141. http://dx.doi.org/10.3354/meps133135

[28] Dahlhoff, E.P. and Menge, B.A. (1996) Influence of Phytoplankton Concentrations and Wave Exposure on the Ecophysiology of Mytilus californianus. Marine Ecology Progress Series, 144, 97-107. http://dx.doi.org/10.3354/meps144097

[29] McQuaid, C.D. and Lindsay, T.L. (2000) Effects of Wave Exposure on Growth and Mortality Rate of the Mussel Perna perna: Bottom-Up Regulating of Intertidal Population. Marine Ecology Progress Series, 206, 147-154. http://dx.doi.org/10.3354/meps206147

[30] Lovatelli, A. (1988) Site Selection for Mollusc Culture. Network of Aquaculture Centres in Asia (NACA), National Inland Fisheries Institute, Kasetsart University Campus Bangkhen, Bangkok.

[31] Aypa, S.M. (1990) Mussel Culture. Regional Seafarming Development and Demonstration Project (RAS), Selected Papers on Mollusc Culture, UNDP/FAO (RAS/90/002), National Inland Fisheries Institute, Kasetsart University Campus Bangkhen, Bangkok.

[32] Fisheries Global Information System (FIGIS) (2005) Perna viridis (Linnaeus, 1758)-Mytilidae. Species Fact Sheet, FAO/SIDP.

[33] Sivalinggam, P.M. (1977) Aquaculture of Green Mussel, Mytilus viridis Linnaeus, in Malaysia. Aquaculture, 11, 297312. http://dx.doi.org/10.1016/0044-8486(77)90079-5

[34] Kripa, V., Mohamed, K.S., Velayudhan, T.S., Joseph, M., Alloycious, P.S and Sharma, J. (2009) Comparison of Growth and Gonad Development of Farmed Green Mussel Perna viridis L. in Three Habitats. Journal of Marine Biological Association of India, 51, 199-204.

[35] Manoj, N.R. and Appukuttan, K.K. (2003) Effect of Temperature on the Development, Growth, Survival and Settlement of Green Mussel Perna viridis (Linnaeus, 1758). Aquaculture Research, 34, 1037-1045. http://dx.doi.org/10.1046/j.1365-2109.2003.00906.x

[36] Barnes, H. (1957) Process of Restoration and Synchronization in Marine Ecology. The Spring Diatom Increase and Spawning of the Common Barnacle Balanus balaboides (L.). Ann Biologiques, 33, 67-85.

[37] Nichols, S. J. (1996) Variations in the Productive Cycle of Dreissena polymorpha in Europe, Russia, and North America. America Zoologist, 36, 311-325.

[38] Myrand, B., Guderley, H. and Himmelman, J.H. (2000) Reproduction and Summer Mortality of Blue Mussels Mytilus edulis in the Mardalen Islands, South Gulf of St. Lawrence. Marine Ecology Progress Series, 197, 193-207. http://dx.doi.org/10.3354/meps197193

[39] Myint, M.U. and Tyler, P.A. (1982) Effects of Temperature, Nutritive and Metal Stressors on the Reproductive Biology of Mytilus edulis. Marine Biology, 67, 209-223. http://dx.doi.org/10.1007/BF00401287

[40] Laxmilatha, P. (2013) A Review of the Green Mussel, Perna viridis Fishery of South West Coast of India. International Journal of Marine Science, 3, 408-416.

[41] Alfaro, A.C., Jeffs, A.G. and Hooker, S.H. (2003) Spatial Variability in Reproductive Behaviour of Green-Lipped Mussel Populations of Northern New Zealand. Molluscan Research, 23, 223-238. http://dx.doi.org/10.1071/MR03007

[42] Reusch, T.B.H. and Chapman, A.R.O. (1997) Persistence and Space Occupancy by Subtidal Blue Mussel Patches. 
Ecological Monographs, 67, 65-87.

[43] Hickman, R.W. (1992) Mussel Cultivation. In: Goslin, E., Ed., The Mussel Mytilus: Ecology, Physiology, Genetics and Culture, Elsevier, Amsterdam, 465-511.

[44] Kripa, V. and Mohamed, K.S. (2008) Green Mussel (Perna viridis) Farming in India, Technology Diffusion Process and Socioeconomic Impacts. Journal of World Aquaculture Society, 9, 612-613. http://dx.doi.org/10.1111/j.1749-7345.2008.00191.x

[45] Kingzett, B. and Salmon, R. (2002) First Nation Shellfish Aquaculture Regional Business Strategy. Kingzett Professional Service Ltd., British Columbia, Canada. 